\title{
Active Breaks and Motor Competencies Development in Primary School: A Systematic Review
}

\author{
Dario Colella $^{1}$, Domenico Monacis ${ }^{1,2}$, Pierpaolo Limone ${ }^{2}$ \\ ${ }^{1}$ Department of Clinical and Experimental Medicine, University of Foggia, Foggia, Italy \\ ${ }^{2}$ Department of Humanities, Cultural Heritage, Education Sciences, University of Foggia, Foggia, Italy \\ Email: dario.colella@unifg.it, domenico.monacis@unifg.it, pierpaolo.limone@unifg.it
}

How to cite this paper: Colella, D., Monacis, D., \& Limone, P. (2020). Active Breaks and Motor Competencies Development in Primary School: A Systematic Review. Advances in Physical Education, 10, 233-250.

https://doi.org/10.4236/ape.2020.103020

Received: May 12, 2020

Accepted: August 3, 2020

Published: August 6, 2020

Copyright $\odot 2020$ by author(s) and Scientific Research Publishing Inc. This work is licensed under the Creative Commons Attribution International License (CC BY 4.0).

http://creativecommons.org/licenses/by/4.0/

\begin{abstract}
The integration of physical activity into the school day is a key aspect for the promotion of "comprehensive school physical activity programs". The proposal of physical activity breaks, known as "Active Breaks" may provide an opportunity to extend the practice of motor activity during curricular hours, alternating too many sedentary moments with short-term physical activity. The aim was to determine the effectiveness of Active Breaks use on motor performance, cognitive engagement and psychological correlates of primary school children. The PRISMA protocol was used to conduct a systematic review of EBSCOhost, PubMed, Scopus and Web of Science databases. A total of 16 articles met inclusion criteria (Active Breaks based Intervention, a quantitative-qualitative analysis between factors included, participants aged 4 to 12 years). Studies based on extracurricular activities, literature reviews, lectures, monographs, dissertations and similar documents were excluded. Results evidence: 1) moderate impact of active breaks in increasing MVPA physical activity levels; 2) low efficacy about cardiorespiratory fitness improvement, and BMI management; 3) moderate improvement in cognitive engagement, positive attitude towards physical activity, perceived self-efficacy and behavior in the classroom. The integration of Active Breaks during the school day contributes to reconsider the pedagogical and didactic impact of the bodily-motor experiences. However, future researches on a rational application and intervention strategies are necessary to evaluate impact and efficacy on didactic process.
\end{abstract}

\section{Keywords}

Active Breaks, Primary School, Physical Activity, Academic Performance, Executive Functions 


\section{Introduction}

The contribution of physical activity for the promotion of health and the prevention of chronic degenerative pathologies has been amply highlighted by international literature, which describes different types of intervention involving different sectors and educational contexts: school, sports start-up, sport, public health, free time, etc.

The international guidelines of the WHO recommend, for children and adolescents ( $5-17$ years), the practice of at least 60 minutes of moderate to intense daily physical activity (WHO, 2014), with an energy expenditure of 3 to 9 METS (Norton et al., 2010). Unfortunately, a large percentage of young people and adolescents in different countries do not comply with these recommendations on the practice of physical activity (WHO, 2014), highlighting an important decline in physical activity levels especially in adolescents (Chan et al., 2017). The increase in overweight and obesity in childhood is an important public health problem in the short to long term (Bullock et al., 2017). Sedentary lifestyles lead to reduced levels of physical activity that strongly affect the rate of obesity, increase the risk factors related to the onset of cardiovascular and metabolic diseases in young people (NCD Risk Factor Collaboration, 2017).

A recent report highlights how in $201681.0 \%$ of students aged $11-17$ years were insufficiently physically active (77.6\% of boys and $84.7 \%$ of girls) and the majority of adolescents do not meet current physical activity guidelines (Guthold et al., 2019). Furthermore, reduced levels of physical activity reflect not only a decline in coordinative and conditional motor performance, especially in the last 15 years (Huotari et al., 2018), but also a deterioration of cognitive functions and of the socio-relational components associated with the practice of motor activity (Kao et al., 2018).

The institutional responses (e.g. the school, public health), to the need to increase the motor commitment time of children and young people to combat sedentary habits, have had a dual orientation: 1) research of curricular didactic paths, multi-interdisciplinary, by the schools themselves, modifying the internal organization; 2) integration of didactic interventions, proposed by territorial bodies and associations, to be carried out in curricular and extra-curricular hours, with the presence of expert teachers in the field of movement and youth sport.

The main actions and organizational methods that promote the practice of motor activities in the developmental age (before the age of 18) are approaches that fall into one of the following three categories (Beets et al., 2016): 1) expansion of opportunities for children to be active (e.g., carrying out activities before entering school or at the end of the lessons or during recreation), 2) extending existing opportunities to practice motor activities (e.g., increasing the amount of time/sessions relating to physical education or the number of hours per week of physical education or starting sport in the afternoon); and/or 3) enhancement of the opportunities to perform the motor activities already present in the curriculum, through strategies aimed at increasing motor engagement time, or in which 
the students are physically active (e.g., increasing the availability of equipment; increase of options related to the various sports activities practicable, identification of spaces and environments to be used simultaneously, etc.).

School is an ideal setting for increasing levels of physical activity, since it is the place where children spend most of the day during childhood. There are numerous interventions proposed to encourage the practice of physical activity in the school context, most of which are structured as multi-component projects (Lonsdale et al., 2016), aimed at promotion of active lifestyles and analysis of the relationships between the increase in levels of physical activity (PAL) and the effects on cognitive functions, academic performance and related psychological-relational factors.

In the school environment, motor activities can be promoted during other hours of classes, intervals and breaks. Regardless of the organizational modalities, it is worth remembering that increasing periods of physical and sports activity at school requires a solid methodological framework and a system for evaluating educational processes and educational results obtained, in order to anchor each activity to the curriculum.

By choosing to alternate and integrate the traditionally theoretical classical didactics with enacting and incorporated didactic strategies, some subjects of disciplines such as mathematics, geography and languages can be taught starting from experiential situations in the gym followed later by theoretical moments. Research in this field show that adding PA to the school day can enhance children's mathematics performance (Sneck et al., 2019).

An emerging trend, which deserves great didactic attention, is represented by the "Active Breaks", i.e. the performance of physical activity in curricular hours, alternating too many static moments with a brief physical activity capable of bringing benefits also for school competences (Carlson et al., 2015).

According to a recent review (Watson et al., 2018), there are currently three ways in which they are currently proposed, in relation to timing, objectives and organizational methods:

- Active breaks as interval/break between two successive lessons;

- Active breaks carried out within the lesson itself;

- Physically active lessons, with integration of physical activity into other disciplinary subjects (e.g. geography, mathematics, geometry, history, etc.).

However, requests and directives from teachers, a very large and articulated school curriculum, greater attention to standardized tests and some constraints related to educational institutions are among the main factors that, in fact, limit the planning of such interventions in the schools (Mahar, 2011; Watson et al., 2018; Schmidt, Benzing, \& Kamer, 2016). Despite studies have shown that short "active breaks" ( 3 - 15 minutes) are effective in increasing attention levels, academic performance, enjoyment, the desire to learn and concentration (Donnelly \& Lambourne, 2011), the type of intervention, duration and methodological approach are quite different. 
The aim of this paper is to provide a review based on effects of active breaks in primary school regarding 1) levels of physical activity, 2) academic performance, 3) motor development and 4) related psychological factors, highlighting strengths and weaknesses about their rational proposal.

\section{Materials and Methods}

Using the PRISMA model (Moher, Liberati, Tetzlaff, \& Altman, 2009), a systematic review of the literature was performed to analyze the relationship between active breaks and physical, cognitive and psychological variables of primary school children. For the bibliographic search four computer databases were used (PubMed, SPORT Discuss, Scopus and Web of Science), selecting articles published between 01/01/2009 and 15/10/2019. Three groups of keywords were identified, using synonyms and similar terms, using the Boolean operator "OR": 1) "active breaks" OR "active school" OR "playtime" OR "playground" OR "recess"; 2) "children" OR "primary school" OR "elementary school" OR "classroom" OR "lesson" OR "school setting"; 3) "physical activity" O, R "physical education" OR "sport" OR "motor activity" OR "sedentary behavior" OR "fitness" OR "energy expenditure". Subsequently, all the categories were combined together using the "AND" operator. The last bibliographic search dates back to $15 / 10 / 2019$

After removing the duplicates, using the Endnote X9 software, Author 1 and 2 screened and analyzed, separately and independently, titles and abstracts to identify eligible articles. If the Author 1 - 2 was uncertain of eligibility, Author 3 assisted with determining inclusion. Following this, full texts were screened and coded based on their ability to meet key criteria for inclusion:

1) Experimental or quasi-experimental studies;

2) Full text and peer-reviewed articles;

3) Intervention based on the proposal of active class breaks (excluding multicomponent studies, in which the motor activity proposed in the classroom is the only condition of intervention);

4) Studies that present a quantitative-qualitative analysis between active breaks and considered factors: a) levels of physical activity, b) academic performance, c) motor development and d) related psychological factors, e) Sample age between 4 - 12 years (UNESCO, 2012) without physical or intellectual disability.

Possible disagreements on the selection of works have been resolved through a critical discussion between the authors. Studies based on extracurricular activities, literature reviews, lectures, monographs, dissertations and similar documents were excluded. The following items were used to critically appraise the existing empirical evidence provided by the studies included in the systematic review: 1) Validity of measures provided or available from external source; 2) Blinded outcome assessment (assessor blinded); 3) Presented baseline characteristics separately for treatment group (age + sex + at least one outcome measure); 4) Dropout described with less than $30 \%$ drop out at follow up. Data from the final in- 
cluded studies was then extracted, summarised and analysed, reporting: 1) author(s)/year of publication/location; 2) experimental design/sample/age; 3 ) intervention; 4) duration of the study; 5) results. This was checked by all the authors.

\section{Results}

The initial database search produced 1087 results; 28 additional works have been added deriving from other sources. After removing the duplicates (513), $602 \mathrm{ar}-$ ticles were analyzed on the basis of title and abstract, and 70 eligible articles were analyzed in full text (Figure 1).

54 studies were excluded because they did not meet the inclusion criteria: multicomponent project $(16 \%)$, intervention not carried out in class or curricular hours (37\%), non-specific focus on active breaks (25\%), no experimental intervention ( $8 \%)$, sample age (8\%), teacher training (4\%) and other variables considered (2\%).

Sixteen studies were selected, analyzed and included in the review. The studies considered present a sample ranging from 18 (Bershwinger \& Brusseau, 2013) to 1346 participants (Calvert et al., 2017), aged 6 - 12 years; 3 studies also include a sample of teachers (Carlson et al., 2015; Martin \& Murtagh, 2015; Martin \& Murtagh, 2016). The studies were conducted in the Netherlands (de Greeff et al., 2016a; de Greeff et al., 2016b), Switzerland (Schmidt, Benzing, \& Kamer, 2016), Italy.

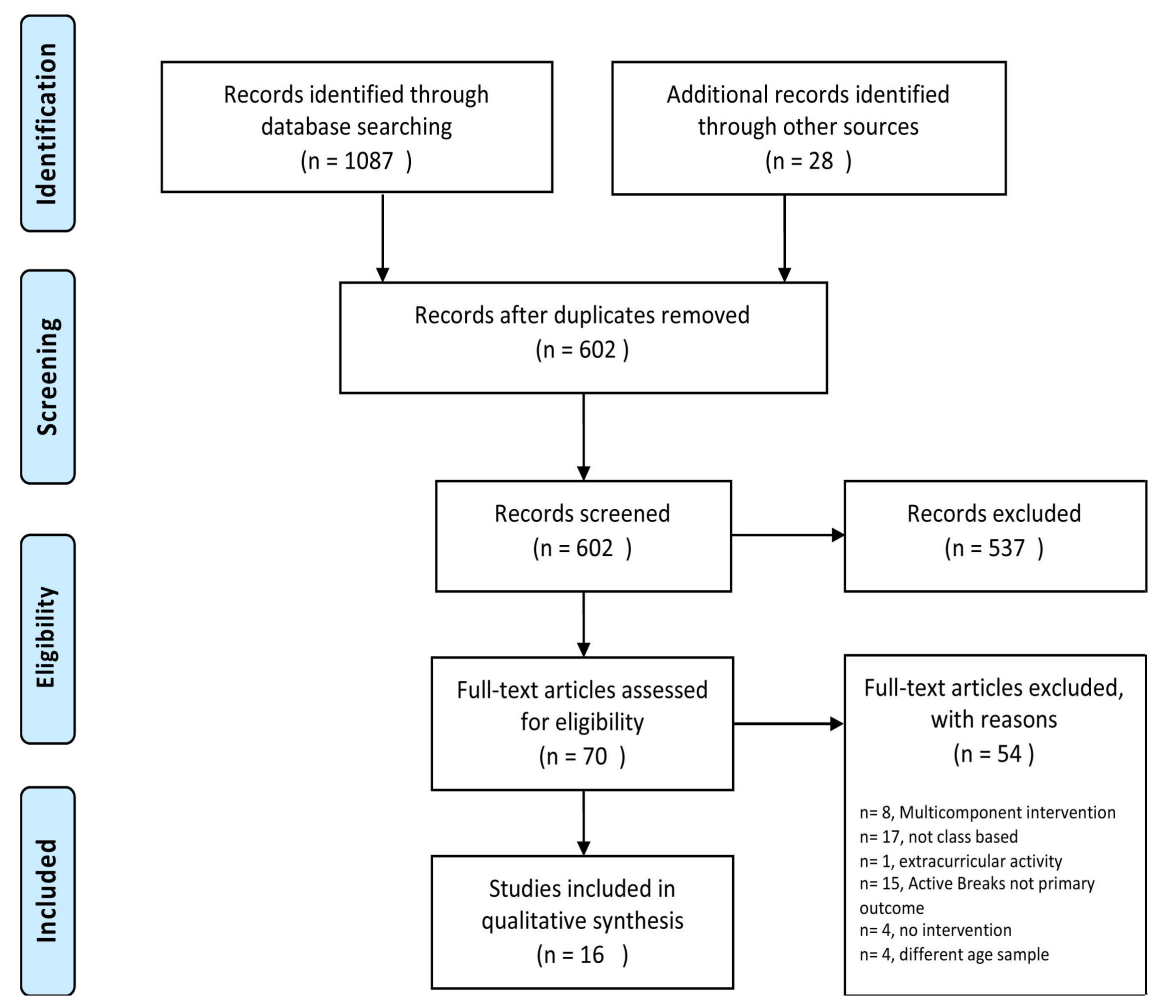

Figure 1. Review process. 
(Calella et al., 2019), Macedonia (Popeska et al., 2018), Ireland (Martin \& Murtagh, 2015; Martin \& Murtagh, 2016), Poland (Glapa et al., 2018), Australia (Watson et al., 2018) and the United States (Bershwinger \& Brusseau, 2013; Calvert et al., 2017; Carlson et al., 2015; Erwin, Koufoudakis, \& Beighle, 2013; Fu \& Burns, 2018; Harris \& Chen, 2018; Whitt-Glover et al., 2011).

Ten studies (Bershwinger \& Brusseau, 2013; Calvert et al., 2017; Carlson et al., 2015; Calella et al., 2019; Erwin, Koufoudakis, \& Beighle, 2013; Martin \& Murtagh, 2015; Martin \& Mourtagh, 2016; Whitt-Glover et al., 2011; Fu \& Burns, 2018) propose to evaluate the relationship between active breaks and MVPA physical activity levels. Three studies analyze the impact of active breaks on children's motor development (de Greeff et al., 2016a; de Greeff et al., 2016b; Harris \& Chen, 2018), while 4 studies consider other associated variables, including academic performance, behavioral factors, executive functions and attention (Carlson et al., 2015; Schmidt, Benzing, \& Kamer, 2016; Watson et al., 2018).

Furthermore, five studies are aimed at analyzing the effects of physical active breaks using technologies (Erwin, Koufoudakis, \& Beighle, 2013; Fu \& Burns, 2018; Popeska et al., 2018; Harris \& Chen, 2018; Glapa et al., 2018), especially in the form of Brain Breaks ${ }^{\circledast}$.

Most of the studies involve a mixed assessment, integrating and combining objective methods (accelerometer or pedometer) with subjective methods (diary, diary, self-report) for the evaluation of correlated factors.

The frequency with which the interventions are proposed is variable, and is closely linked to their duration:

- Interventions $>10$ minutes, proposed maximum 2 times a day or 2 - 3 times a week;

- 3 - 5 minutes interventions, also offered 3 - 5 times a day, every day.

The duration of the intervention protocol ranges from a minimum of 5 days (Erwin, Koufoudakis, \& Beighle, 2013) to a maximum of 2 years (Calvert et al., 2017): $46 \%$ of the studies have an observation period of less than 3 months, $26 \%$ between 3 months and one year, while the remaining $26 \%$ has a duration greater than or equal to one school year.

Eight studies (60\%) use the accelerometer (7 studies) or the pedometer (1 study) as a tool for the objective assessment of physical activity levels, while the SOFIT (6\%), based on direct observation, falls among the tools for subjective evaluation.

To assess motor performance, the Eurofit (13\%) and Fitnessgram protocols are used, especially the PACER Test (13\%). The questionnaires proposed for the analysis of correlated factors are generally adapted versions of already structured questionnaires, including Attitudes to Physical Activity Scale (Mok et al., 2015), 60-item Classroom Behavior and Assets Scale (Lee et al., 2009), PANSAS-C (short version; Ebesutani et al., 2012), or derived from other studies and intervention protocols (Androutsos et al., 2014). The Golden Stroop Test (Strauss, Sherman, \& 
Spreen, 2006), the Digit Span Backward and Visual Span Backward Test (Wechsler, 1987), M-WCST (Cianchetti, Corona, \& Foscoliano, 2007) and D2-R Test (Brickenkamp \& Zillmer, 1998) are used for the evaluation of executive functions.

School performance is assessed by the WARP test (Wheldall \& Madelaine, 2013) and Westwood One Minute Tests of Basic Number Facts (Westwood, 2000). The results show an increase in MVPA physical activity levels in 53\% of the studies; only $13 \%$ did not show significance between LAF and active breaks.

As regards the analysis of motor performance, the results are quite conflicting; however, there is limited evidence concerning the improvement of cardiorespiratory capacity (Fu \& Burns, 2018) associated with the practice with AVG, and the management of BMI (de Greeff et al., 2016a).

Regarding the associated psychological factors and cognitive functions, some studies show an improvement in cognitive engagement and attention factors (Schmidt, Benzing, \& Kamer, 2016; Popeska et al., 2018), perceived self-efficacy (Watson et al., 2018) and classroom behavior (Whitt-Glover et al., 2011); only one study did not report statistically significant data (Fu \& Burns, 2018).

Table 1 shows a more detailed analysis of the studies reviewed.

\section{Discussion}

The integration of physical activity into the school day is a key aspect for the promotion of "comprehensive school physical activity programs". However, the attention paid to raising students' academic performance, the limited time available and some institutional constraints are factors that limit the opportunities for the practice of physical activity.

Short periods of this activity, carried out in the classroom, represent a modern intervention strategy to increase the levels of physical activity in the school environment. From a methodological point of view the teacher can choose whether to temporarily interrupt the didactic activities and to propose a short pause of physical activity, active breaks, or to associate this activity to the contents of the lesson, active lessons (Turner \& Chaloupka, 2016).

The present literature review found 16 studies evaluating the effects of active breaks in primary school on 1) levels of physical activity, 2) academic performance, 3) motor development and 4) related psychological factors. Most of the studies showed an improvement in the variables considered, following the participation in physical activity programs in the classroom.

As far as physical activity and academic performance are concerned, the results are discordant with previous reviews in which it was highlighted that the general level of physical activity was positively associatedor was not associated with results related to the academic field (Szabo-Reed et al., 2019). This is probably linked to the different type of activity proposed. All the works included in the current revision have tended to show an increase in physical activity levels.

The effects on acute improvement of behavioral factors, as well as cognitive and psychological factors, are consistent with the international literature analyzed. 
Table 1. Reviewed studies.

\begin{tabular}{|c|c|c|c|c|c|c|c|}
\hline $\begin{array}{l}\text { Authors, } \\
\text { Years }\end{array}$ & Country & Sample & Objective & Intervention & Durata & $\begin{array}{l}\text { Assessment } \\
\text { Tools }\end{array}$ & Results \\
\hline $\begin{array}{l}\text { Whitt-Glover } \\
\text { et al., } 2011\end{array}$ & $\begin{array}{l}\text { Forsyth, } \\
\text { North } \\
\text { Carolina } \\
\text { (USA) }\end{array}$ & $\begin{array}{c}\text { EG } \\
\text { (immediate } \\
\text { intervention) = 4 } \\
\text { schools; } \\
\text { ES_2 (delayed } \\
\text { intervention) = } 3 \\
\text { schools; } \\
\text { CG = } 1 \text { school; } \\
\text { Age }=8 \text { - } 11 \text { years }\end{array}$ & $\begin{array}{l}\text { Evaluated a policy } \\
\text { implementation } \\
\text { intervention for to } \\
\text { increase in-school PA } \\
\text { in elementary schools } \\
\text { in Forsyth County, } \\
\text { North Carolina, } \\
\text { in a randomized } \\
\text { study with a } \\
\text { delayed intervention } \\
\text { control group }\end{array}$ & $\begin{array}{l}\text { Introduce } \\
\text { 10-minute } \\
\text { PA breaks in } \\
\text { classrooms } \\
\text { on schedules } \\
\text { determined } \\
\text { by teachers }\end{array}$ & $\begin{array}{c}2 \\
\text { semesters }\end{array}$ & $\begin{array}{c}\text { SOFIT } \\
\text { (adaptedversion; } \\
\text { Samuels et al., } \\
\text { 2010) }\end{array}$ & $\begin{array}{l}\text { Students in classrooms } \\
\text { engaged in Instant } \\
\text { Recess exhibited } \\
\text { statistically significant } \\
\text { increases in light (51\%) } \\
\text { and moderate-intensity } \\
(16 \%) \text { PA and increases } \\
\text { in time spent in on-task } \\
\text { behavior (11\%). } \\
\text { Control schools } \\
\text { experienced similar } \\
\text { benefits after they } \\
\text { began implementing } \\
\text { Instant Recess. }\end{array}$ \\
\hline $\begin{array}{l}\text { Bershwinger } \\
\text { \& Brusseau, } \\
2013\end{array}$ & $\begin{array}{l}\text { Western } \\
\text { New York, } \\
\text { USA }\end{array}$ & $\begin{array}{c}\mathrm{N}=18 \\
\mathrm{M}=11, \\
\mathrm{~F}=7 ; \\
\text { Age }=9.2 \pm 4 \\
\text { years }\end{array}$ & $\begin{array}{l}\text { Determine the } \\
\text { impact of classroom } \\
\text { teacher led activity } \\
\text { breaks on the step } \\
\text { counts and } \\
\text { moderate-to-vigorous } \\
\text { physical activity } \\
\text { (MVPA) of } 4 \text { th grade } \\
\text { children at school }\end{array}$ & $\begin{array}{c}5 \text { - } 15 \text { minutes } \\
\text { of physical } \\
\text { activity, } \\
1 \text { - } 3 \text { times } \\
\text { a day }\end{array}$ & 2 weeks & $\begin{array}{l}\text { Accelerometers, } \\
\text { The New } \\
\text { Lifestyles } \\
\text { NL-1000 } \\
\text { (New Lifestyles, } \\
\text { Lee Summit, } \\
\text { MO) }\end{array}$ & $\begin{array}{l}\text { Children significantly } \\
\text { increased both their } \\
\text { steps and MVPA. }\end{array}$ \\
\hline $\begin{array}{c}\text { Erwin, } \\
\text { Koufoudakis, } \\
\text { \& Beighle, } \\
2013\end{array}$ & USA & $\begin{array}{c}\mathrm{N}=54, \\
\mathrm{M}=27, \\
\mathrm{~F}=27 ; \\
\text { Age }=8-12 \text { years; }\end{array}$ & $\begin{array}{l}\text { Describe PA levels } \\
\text { and intensity } \\
\text { during indoor } \\
\text { recess using } \\
\text { PA dance videos }\end{array}$ & $\begin{array}{c}15 \text { - } 20 \text { minutes of } \\
\text { PA using } \\
\text { DVD } \\
\text { dance videos }\end{array}$ & 5 days & $\begin{array}{l}\text { Accelerometers, } \\
\text { ActiGraph }\end{array}$ & $\begin{array}{c}\text { Participants averaged } \\
17.66 \text { minutes in } \\
\text { indoor recess (22.22\%) } \\
\text { was spent in } \\
\text { moderate-to-vigorous } \\
\text { physical activity } \\
\text { (MVPA), and } 45.70 \% \\
\text { in low-intensity } \\
\text { physical activity (LPA) } \\
\text { totaling } 67.92 \% \text { of } \\
\text { total recess time. } \\
\text { Boys accumulated } \\
\text { a higher percentage } \\
\text { of MVPA and total PA } \\
\text { compared to girls. }\end{array}$ \\
\hline $\begin{array}{l}\text { Carlson } \\
\text { et al., } 2015\end{array}$ & $\begin{array}{c}\text { California, } \\
\text { USA }\end{array}$ & $\begin{array}{l}\mathrm{N} \text { (students) } \\
\quad=1322 ; \\
\text { Age = } 6-11 \\
\quad \text { years; } \\
\text { N (teachers) } \\
\quad=397 ;\end{array}$ & $\begin{array}{l}\text { To investigate the } \\
\text { relation of classroom } \\
\text { physical activity } \\
\text { breaks to students' } \\
\text { physical activity and } \\
\text { classroom behavior }\end{array}$ & $\begin{array}{l}10 \text { minutes } \\
\text { of classroom } \\
\text { activity } \\
\text { breaks a day }\end{array}$ & 1 years & $\begin{array}{l}\text { Accelerometers } \\
\text { Actigraph } \\
\text { GT3X+, } \\
\text { teacher's } \\
\text { questionnaire, } \\
\text { an adapted } \\
\text { version of del } \\
\text { 60-item } \\
\text { Classroom } \\
\text { Behavior and } \\
\text { Assets Scale } \\
\text { (Lee et al., 2009) }\end{array}$ & $\begin{array}{l}\text { Minutes/day of activity } \\
\text { breaks was positively } \\
\text { associated with } \\
\text { students' MVPA. } \\
\text { Implementation } \\
\text { was negatively } \\
\text { associated with } \\
\text { students having a } \\
\text { lack of effort in class, } \\
\text { and student MVPA } \\
\text { was negatively } \\
\text { associated } \\
\text { with students being } \\
\text { off task or inattentive } \\
\text { in the classroom. }\end{array}$ \\
\hline
\end{tabular}




\section{Continued}

\begin{tabular}{|c|c|c|c|c|c|c|c|}
\hline $\begin{array}{l}\text { Martin \& } \\
\text { Murtagh, } \\
2015\end{array}$ & $\begin{array}{l}\text { Limerick, } \\
\text { Ireland }\end{array}$ & $\begin{array}{l}\mathrm{N}=28, \mathrm{M}=14 \\
\quad \mathrm{~F}=14 ; \\
\text { Age = } 8-9 \text { years; } \\
\quad 1 \text { teacher, } \\
\text { age = } 33 \text { years }\end{array}$ & $\begin{array}{l}\text { Evaluates the effects } \\
\text { of a behaviour change } \\
\text { intervention, which } \\
\text { encourages the } \\
\text { integration of } \\
\text { physical activity } \\
\text { into the teaching of } \\
\text { academic lessons, on } \\
\text { physical activity } \\
\text { levels of students. }\end{array}$ & $\begin{array}{l}\text { Two active } \\
\text { intervention } \\
\text { lessons } \\
\text { (one English } \\
\text { and one } \\
\text { Mathematics) } \\
\text { lasting an } \\
\text { average of } \\
18 \text { min } \\
\text { (5.5\% of the } \\
\text { school day) }\end{array}$ & 5 days & $\begin{array}{l}\text { Accelerometers, } \\
\text { Toy Box (adapted } \\
\text { from Androutsos } \\
\text { et al., 2014) }\end{array}$ & $\begin{array}{l}\text { The teacher and } \\
\text { students were very } \\
\text { satisfied with the } \\
\text { programme. Therefore, } \\
\text { changing teacher } \\
\text { behavior towards } \\
\text { using physically } \\
\text { active teaching methods } \\
\text { is a promising way of } \\
\text { increasing children's } \\
\text { physical activity levels. }\end{array}$ \\
\hline $\begin{array}{l}\text { de Greeff } \\
\text { et al., 2016a }\end{array}$ & Netherlands & $\begin{array}{c}\mathrm{N}=388 \\
\text { Age }=8.1 \pm 0.7 \\
\text { years; } \\
\text { EG }=181 \\
\text { CG }=195\end{array}$ & $\begin{array}{l}\text { Investigate effects } \\
\text { of physically active } \\
\text { academic lessons on } \\
\text { body mass index } \\
\text { (BMI) and physical } \\
\text { fitness in primary } \\
\text { school children }\end{array}$ & $\begin{array}{l}\text { Physically } \\
\text { active } \\
\text { academic } \\
\text { lessons for } \\
22 \text { weeks }\end{array}$ & 22 weeks & $\begin{array}{l}\text { Test Eurofit } \\
\quad \text { (Adam } \\
\text { et al., 1988) }\end{array}$ & $\begin{array}{l}\text { Positive effects on BMI } \\
\text { in third-grade children, } \\
\text { but had no effects on } \\
\text { cardiovascular and } \\
\text { muscular fitness. }\end{array}$ \\
\hline $\begin{array}{l}\text { de Greeff } \\
\text { et al., 2016b }\end{array}$ & Netherlands & $\begin{array}{c}\mathrm{N}=499 \\
\mathrm{M}=226 \\
\mathrm{~F}=273 ; \\
\text { Age }=8.1 \pm 0.7 \\
\text { years; } \\
\mathrm{EG}=249 ; \\
\mathrm{CG}=250 ;\end{array}$ & $\begin{array}{l}\text { Investigate the effects } \\
\text { of physically active } \\
\text { academic lessons } \\
\text { on cardiovascular } \\
\text { fitness, muscular } \\
\text { fitness and } \\
\text { executive functions }\end{array}$ & $\begin{array}{l}\text { Physically } \\
\text { active } \\
\text { academic } \\
\text { lessons for } 2 \\
\text { consecutive } \\
\text { school years, } \\
22 \text { weeks } \\
\text { per year, } \\
\text { three times a } \\
\text { week, with a } \\
\text { duration of } \\
20 \text { - } 30 \text { min } \\
\text { per lesson }\end{array}$ & 2 years & $\begin{array}{c}\text { Test Eurofit } \\
\text { (Adam et al., } \\
\text { 1988) } \\
\text { Golden Stroop } \\
\text { (Strauss, } \\
\text { Sherman, \& } \\
\text { Spreen, 2006), } \\
\text { Digit span } \\
\text { backward and } \\
\text { Visual span } \\
\text { backward } \\
\text { (Wechsler, 1987), } \\
\text { M-WCST } \\
\text { (Cianchetti, } \\
\text { Corona, \& } \\
\text { Foscoliano, 2007) }\end{array}$ & $\begin{array}{l}\text { Larger improvement } \\
\text { in speed-coordination } \\
\text { and a lower } \\
\text { improvement in } \\
\text { static strength for the } \\
\text { intervention group } \\
\text { compared with the } \\
\text { control group. } \\
\text { No significant change } \\
\text { in executive functions. }\end{array}$ \\
\hline $\begin{array}{c}\text { Schmidt, } \\
\text { Benzing, \& } \\
\text { Kamer, 2016 }\end{array}$ & $\begin{array}{c}\text { Bern, } \\
\text { Switzerland }\end{array}$ & $\begin{array}{c}\mathrm{N}=92 \\
\text { Age }= \\
11.77 \pm 0.41 \\
\text { years }\end{array}$ & $\begin{array}{l}\text { Disentangle the } \\
\text { separate and/or } \\
\text { combined effects } \\
\text { of physical exertion } \\
\text { and cognitive } \\
\text { engagement induced } \\
\text { by physical activity } \\
\text { breaks on primary } \\
\text { school children's } \\
\text { attention }\end{array}$ & $\begin{array}{l}4 \text { experimental } \\
\text { conditions: } \\
\text { 1) combo group } \\
\text { (physical activity } \\
\text { with high cognitive } \\
\text { demands), } \\
\text { 2) cognition } \\
\text { group (sedentary } \\
\text { with high } \\
\text { cognitive } \\
\text { demands), } \\
\text { 3) physical } \\
\text { group } \\
\text { (physical } \\
\text { activity with } \\
\text { low cognitive } \\
\text { demands), } \\
\text { and } \\
\text { 4) control group } \\
\text { (sedentary with } \\
\text { low cognitive } \\
\text { demands) }\end{array}$ & 3 weeks & $\begin{array}{c}\text { D2-R test } \\
\text { (Brickenkamp \& } \\
\text { Zillmer, 1998); } \\
\text { PANSAS-C } \\
\text { short version, } \\
\text { (Ebesutani } \\
\text { et al., 2012); } \\
\text { Borg Scale } \\
\text { (Borg, 1998) }\end{array}$ & $\begin{array}{l}\text { Positive affect during } \\
\text { the interventions } \\
\text { mediated the effect } \\
\text { between cognitive } \\
\text { engagement and } \\
\text { focused attention } \\
\text { as well as between } \\
\text { cognitive engagement } \\
\text { and processing speed. } \\
\text { Cognitive engagement } \\
\text { was the crucial factor } \\
\text { leading to increased } \\
\text { focused attention and } \\
\text { enhanced } \\
\text { processing speed. }\end{array}$ \\
\hline
\end{tabular}




\section{Continued}

\begin{tabular}{|c|c|c|c|}
\hline & & $\mathrm{N}=197$ & Assess the \\
\hline & & Age $=8.9 \pm 1.0$ & effectiveness of the \\
\hline & & years; & "Active Classrooms" \\
\hline & & $\begin{array}{c}\mathrm{EG}=98 \text { students } \\
\text { age }=8.8 \pm 1.0\end{array}$ & $\begin{array}{l}\text { intervention, which } \\
\text { integrates movement }\end{array}$ \\
\hline $\begin{array}{l}\text { Martin \& } \\
\text { Mourtagh, }\end{array}$ & Limerick, & years, & into academic lessons, \\
\hline 2016 & & $\begin{array}{c}n=5 \text { teachers; } \\
\text { CG }=117\end{array}$ & on MVPA levels of \\
\hline & & students, & children during \\
\hline & & age $=9.1 \pm 0.9$ & class-time and \\
\hline & & $\begin{array}{c}\text { years, } \\
\mathrm{n}=5 \text { teachers; }\end{array}$ & $\begin{array}{l}\text { throughout the } \\
\text { school day }\end{array}$ \\
\hline
\end{tabular}

Active academic lessons taught by the classroom teacher over an 8 week period.

$\begin{array}{cc} & \text { Accelerometers, } \\ \text { Toy Box } \\ \text { 8 weeks } \\ \text { (adapted } \\ \text { from Androutsos } \\ \text { et al., 2014) }\end{array}$

Accelerometers,

Physical Activity of 1 - 5 minutes, 6 - 10 minutes or $>10$ minutes total school-day step counts

\begin{tabular}{|c|c|c|c|}
\hline \multirow{6}{*}{$\begin{array}{c}\text { Fu \& Burns, } \\
2018\end{array}$} & \multirow{4}{*}{$\begin{array}{c}\text { Western } \\
\text { USA }\end{array}$} & & \multirow{6}{*}{$\begin{array}{l}\text { Explore the effect of } \\
\text { an active video } \\
\text { gaming (AVG) } \\
\text { lassroom curriculum } \\
\text { on health-related } \\
\text { fitness, school day } \\
\text { steps, and motivation } \\
\text { in sixth graders }\end{array}$} \\
\hline & & $\begin{array}{l}\mathrm{N}=62, \\
\mathrm{M}=30,\end{array}$ & \\
\hline & & $\mathrm{F}=36$ & \\
\hline & & Age $=11.6 \pm 0.5$ & \\
\hline & & $\mathrm{EG}=33$ & \\
\hline & & $\mathrm{GC}=32$ & \\
\hline
\end{tabular}

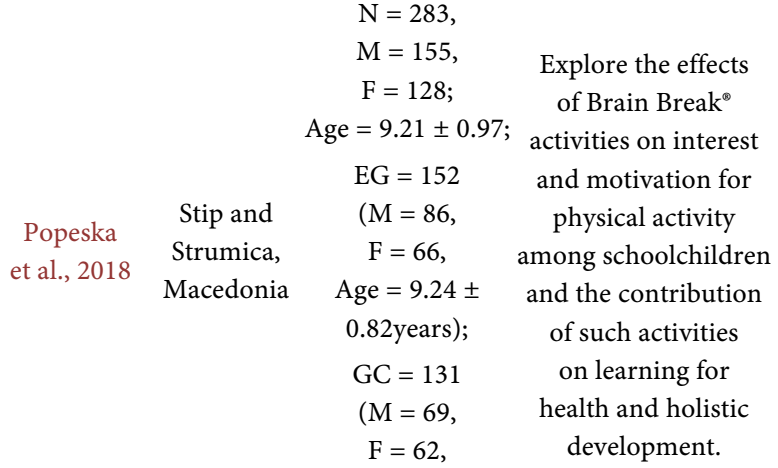

Popeska et al., 2018

Age $=9.18 \pm 1.13$

Significant difference for change in daily class time MVPA levels was identified between the treatment and control groups from pre- to post-intervention and this difference was maintained at follow-up. No significant difference for change in school day MVPA levels from pre- to post-intervention or follow-up. Teachers were highly satisfied with the programme.

CBPA appears to provide equal PA benefits for both genders, and to potentially minimize the decline in PA, especially among older students

PACER Test

(Meredith \& Welk, 2010), pedometer and self-report (Gao et al., 2008; Harter, 1978; for 30 minutes per day, 3 days per week, for 18 weeks

18 weeks

Scanlan et al., 1993;

Ommundsen et al., 2008;

Xiang et al., 2006; Guay et al., 2000;

Goudas \&

Dermitzaki, 2004)

Interventions in classroom settings-based Brain Break ${ }^{\oplus}$ video exercises were 3 months introduced in the experimental group during a period of three months
Significant group $\times$ time interaction for PACES laps. No statistically significant interactions for step counts or any of the motivational variables

\section{Questionnaire \\ Attitudes toward Physical} Activity Scale, (Mok et al., 2015)
Positive effects of the applied Brain Break ${ }^{\infty}$ video exercises as an interventional program. The study confirms the effect of application of Brain Break ${ }^{\oplus}$ video exercises on children's attitudes for physical activity, motivation for PA, internalization of movement habits as personal good. 


\section{Continued}

\begin{tabular}{|c|c|c|c|c|c|c|c|}
\hline $\begin{array}{c}\text { Harris \& } \\
\text { Chen, } 2018\end{array}$ & $\begin{array}{l}\text { Michigan, } \\
\text { USA }\end{array}$ & $\begin{array}{c}\mathrm{N}=116, \\
\mathrm{M}=59, \\
\mathrm{~F}=57 ; \\
\text { age }=10-11 \\
\text { years; } \\
\text { EG Fitbit-O = } 29 ; \\
\text { GS PAEB-C }=31 ; \\
\text { CG }=56 ;\end{array}$ & $\begin{array}{c}\text { Examine } \\
\text { the effects of a } \\
\text { 4-week } \\
\text { technology-enhanced } \\
\text { physical activity (PA) } \\
\text { interventions } \\
\text { on students' real-time } \\
\text { daily PA and } \\
\text { aerobic fitness levels }\end{array}$ & $\begin{array}{l}\text { Intervention group } \\
\text { participating in } \\
\text { daily physical } \\
\text { activity engaging } \\
\text { the brain with } \\
\text { Fitbit Challenge } \\
\text { (PAEB-C), another } \\
\text { intervention group } \\
\text { wearing Fitbits } \\
\text { only (Fitbit-O) } \\
\text { daily, five days per } \\
\text { week, or the } \\
\text { comparison group }\end{array}$ & 4 weeks & $\begin{array}{c}\text { PACER } \\
\left(\text { FitnessGram }{ }^{\oplus}\right)\end{array}$ & $\begin{array}{l}\text { The PAEB-C students } \\
\text { showed significantly } \\
\text { higher steps and } \\
\text { minutes of being } \\
\text { very active and } \\
\text { fairly active and } \\
\text { lower minutes of } \\
\text { being sedentary } \\
\text { daily than the } \\
\text { Fitbit-O group. }\end{array}$ \\
\hline $\begin{array}{l}\text { Glapa } \\
\text { et al., } 2018\end{array}$ & Poland & $\begin{array}{c}\mathrm{N}=326, \mathrm{M}=170, \\
\mathrm{~F}=156 ; \text { Age }= \\
9.74 \pm 1.06 \text { years; } \\
\mathrm{EG}=264 \\
(\mathrm{M}=132, \mathrm{~F}=132, \\
\text { Age }=9.6 \pm 1.08 \\
\text { years }) ; \\
\mathrm{GC}=62(\mathrm{M}=38, \\
\mathrm{F}=24, \text { Age }=10.1 \\
\pm 0.92 \text { years })\end{array}$ & $\begin{array}{l}\text { Examine the } \\
\text { effectiveness of the } \\
\text { Brain Breaks }{ }^{\oplus} \text { Physical } \\
\text { Activity Solutions in } \\
\text { changing attitudes } \\
\text { toward physical } \\
\text { activity of school } \\
\text { children in a } \\
\text { community in Poland }\end{array}$ & $\begin{array}{l}\text { Physical activities } \\
\text { two times per day } \\
\text { in three to five } \\
\text { minutes using Brain } \\
\text { Breaks }{ }^{\oplus} \text { videos for } \\
\text { four months }\end{array}$ & 4 months & $\begin{array}{c}\text { Attitudes toward } \\
\text { Physical Activity } \\
\text { Scale } \\
\text { (Mok et al., 2015) }\end{array}$ & $\begin{array}{l}\text { Time-by-group } \\
\text { interaction effects } \\
\text { in "Self-efficacy on } \\
\text { learning with } \\
\text { video exercises". }\end{array}$ \\
\hline $\begin{array}{l}\text { Watson } \\
\text { et al., } 2018\end{array}$ & $\begin{array}{c}\text { Melbourne, } \\
\text { Australia }\end{array}$ & $\begin{array}{c}\mathrm{N}=374, \\
\text { Age }=8-10 \\
\text { years; } \\
\mathrm{GS}=123 \\
(\mathrm{M}=50 \%, \\
\mathrm{F}=50 \%, \\
\text { Age }=9.22 \pm 0.61 \\
\text { years }) \\
\mathrm{GC}=218 \\
(\mathrm{M}=54 \%, \\
\mathrm{F}=46 \%, \\
\text { Age }=9.07 \pm 0.63 \\
\text { years })\end{array}$ & $\begin{array}{l}\text { Assess the feasibility } \\
\text { and efficacy of a } \\
\text { 6-week pilot active } \\
\text { break program } \\
\text { (ACTI-BREAK) } \\
\text { on academic } \\
\text { achievement, } \\
\text { classroom } \\
\text { behaviour and } \\
\text { physical activity }\end{array}$ & $\begin{array}{l}3 \times 5 \text { min active } \\
\text { breaks into } \\
\text { classroom routine } \\
\text { daily }\end{array}$ & 6 weeks & $\begin{array}{c}\text { WARP test } \\
\text { (Wheldall \& } \\
\text { Madelaine, 2013), } \\
\text { Westwood One } \\
\text { Minute Tests of } \\
\text { Basic Number Facts } \\
\text { (Westwood, 2000); } \\
\text { Direct Behaviour } \\
\text { Rating Scale e } \\
\text { Classroom } \\
\text { Behaviour } \\
\text { and Assets } \\
\text { Survey-Teacher } \\
\text { (adapted; } \\
\text { Chafouleas } \\
\text { et al., 2013); } \\
\text { accelerometers }\end{array}$ & $\begin{array}{l}\text { Significant intervention } \\
\text { effects were found for } \\
\text { classroom behavior } \\
\text { at the individual level; } \\
\text { effects were stronger } \\
\text { for boys (than girls. } \\
\text { No effect was found } \\
\text { for classroom behavior } \\
\text { at the whole class level, } \\
\text { reading, math or } \\
\text { physical activity. } \\
\text { PP findings were } \\
\text { similar. }\end{array}$ \\
\hline $\begin{array}{l}\text { Calella } \\
\text { et al., } 2019\end{array}$ & Italy & $\begin{array}{c}n=47 \\
\text { Age }=8-9 \text { years }\end{array}$ & $\begin{array}{l}\text { Develop and } \\
\text { evaluate the } \\
\text { feasibility of a } \\
\text { classroom-based } \\
\text { intervention which } \\
\text { integrates PA } \\
\text { during the school } \\
\text { time, and assess } \\
\text { its potential effect } \\
\text { on reducing } \\
\text { inactivity in primary } \\
\text { school children }\end{array}$ & $\begin{array}{l}\text { Four exercises, based } \\
\text { on fundamental } \\
\text { movement skills } \\
\text { and gross motor } \\
\text { coordination, which } \\
\text { differed for each } \\
\text { session at a set time: } \\
\text {-1st session } 8: 40 \\
\text { Stretching; }-2^{\text {nd }} \\
\text { session 9:40 Running } \\
\text { and jump; }-3^{\text {rd }} \\
\text { session } 11: 40 \text { Upper } \\
\text { limb exercises; } \\
\text {-4th session } 12: 40 \\
\text { Lower limb exercises }\end{array}$ & 4 months & $\begin{array}{l}\text { Acti Graph GT1M; } \\
\text { questionnaire }\end{array}$ & $\begin{array}{l}\text { Reduction of inactivity } \\
\text { of } 12 \text { min and an } \\
\text { equivalent increase in } \\
\text { PA levels ( } 5 \text { min } \\
\text { MVPA). Girls showed } \\
\text { lower time spent in } \\
\text { light and moderate PA } \\
\text { and higher amount of } \\
\text { inactivity than boys and } \\
\text { responded better to the } \\
\text { intervention. The } \\
\text { satisfaction of children } \\
\text { and teachers was high. }\end{array}$ \\
\hline
\end{tabular}


A recent literature review supports how the regular practice of physical activity, short breaks and interventions aimed at increasing levels of physical activity positively encourage children's cognitive functioning (Donnelly et al., 2016). Some studies have shown a positive association between the practice of physical activity before the lesson (for example during the break/recreation) and the behavior in the classroom during the following lessons (Whitt-Glover et al., 2011). One study reported a mild to moderate improvement in the attention focused following the proposal of active breaks for primary school students (Mahar, 2011).

The positive effects on neuro-psychological and cognitive factors are transferable also in contexts and populations different from the purely scholastic one.

Active breaks, carried out for example during the working day, are generally proposed to promote active lifestyles to increase safety in the workplace (Dewitt et al., 2019), highlighting positive effects of short periods of physical exercise on neuro-cognitive factors on an adult population.

The importance of physical activity in the classroom was also supported by the project Physical Activity across the Curriculum (PACC; Donnelly et al., 2017).

The physically active school lessons of moderate intensity have in fact improved the overall performance on a standardized test, related to academic performance, by $6 \%$ compared to a reduction of $1 \%$ for the control group. The results show a slight increase in the number of students per week, compared to students with less than 75 minutes of PAAC per week (Donnelly \& Lambourne, 2011).

Therefore, the interruption of educational activities resulting in a proposal for physical activity would represent an important and significant strategy to improve behavior during subsequent activities and to involve students more in the contents of the lesson, generating a favorable and competence-oriented motivational climate.

However, this hypothesis is purely speculative, and more research is needed to confirm it. These results can encourage teachers to consider implementing physical activity programs in the classroom, alleviating concerns about reducing on-task behavior due to the interruption of school routines.

Furthermore, an emerging trend that deserves great attention is represented by the "Brain Breaks", that is, the holding of short intervals reserved for physical activity in curricular time mediated by technology. The proposal of tasks can take place through organizational methods and with different learning objectives aimed at the development of physical efficiency, at the acquisition of motor skills and interdisciplinary and transversal skills, even if the evidence in this regard is quite limited. In developmental age this contribution is particularly important because it allows the teacher to re-orient the use of video games/technologies to promote, at the same time, motor activities in a natural and virtual environment at the same time.

Results emphasize not only how these methods are effective for increasing the 
levels of physical activity in a sample of primary school children, but also how these strategies are favorably received and used by the teachers themselves, generating a continuity of interventions.

The use of technologies in curricular teaching in relation to active breaks can therefore be envisaged first of all to expand the set of contents and equipment traditionally used in the classroom and in the school context in general, to develop the students' motivations and their availability to the use, allowing the teacher to use diversified environments, mobilizing useful factors for the qualitative improvement of the didactic process.

\section{Methodological and Didactic Implications}

The opportunity to carry out added periods or intervals in which to practice physical activities can help teachers (both generalist and PE) to anchor these experiences in a pedagogical and curricular teaching framework in which takes place the learning and health promotion processes of the student.

Not being able to change the number of curriculars aimed at physical education, introduce a daily and weekly break, or a different organized school recreation, allowing to integrate teaching strategies to improve the playful atmosphere in the classroom, attention and intrinsic motivation to motor activity, developing life skills and academic performance, using the interval most appreciated by the students.

Short active breaks established a didactic intervention strategy whose aim is not simply the improvement of physical activity levels and the motor skills development; this method of intervention should be conceived and developed in continuity with the disciplinary contents, expanding and extending new and different opportunities for interdisciplinary and transversal relationships. Related to physical education, this would represent an opportunity to link its own contents and learnings, with other disciplinary fields.

Interventions should be structured and proposed in relation to specific objectives and aimed at:

- Increase physical efficiency;

- Increase in physical activity levels;

- Allow motor skills learning and motor development coordination;

- Development of interdiscpilinary relationships between school learnings.

The contents, moreover, should be proposed through different teaching styles, which implies the mediating role of teacher in the learning-teaching process.

The classroom environment or other school setting takes on pleasant, emotionally engaging places, where the usual day based on theoretical teachings is interrupted, dividing the curricular school-time through bodily-motor experiences that contribute to make learnings significant.

In relation to the effectiveness of the educational and organizational proposal, it is not possible to draw definitive conclusions regarding the organizational aspects, because of the wide heterogeneity of the factors involved and the related results. 


\section{Conclusion}

The didactic choice to carry out the recreation in a different way from the traditional one or to offer active breaks during the school day, contributes to reconsider the pedagogical and didactic contribution of the bodily-motor experiences.

Recently, the school setting has been considered the privileged context to educate children to acquire not only motor skills and knowledge but also healthy habits and develop the educational process for body and movement.

If studies on the risks of children's sedentary behavior and the benefits of motor experience on cognitive-motor and social development processes continue to increase, provide and integrate motor and physical activity in the school day of children and young people will become more important.

This organizational strategy in primary school can continue in the following ages, generating in the individual the perception of the value of physical activity and taking place in different places, for example the workplace, with significant benefits for the health of citizens.

The future studies envisaged concern, in particular the relation between 1) type of intervention, 2) duration of the intervention, 3) content and still teaching, 4) continuity with interdisciplinary learning, 5) methods and assessment tools, to determine the effectiveness of these organizational methods and to underline.

Finally, in the perspective of body and movement education, the activation of intervals in which to carry out physical activities during the day is especially appropriate when children spent a lot of time sitting in the classroom. Active break can be understood as an indispensable part of the school day, provided it is integrated on a solid methodological basis.

Future research on a rational application and proposal of active breaks, therefore, it is necessary to observe directions, teaching and organizational, evaluating educational processes and outcomes.

\section{Conflicts of Interest}

The authors declare no conflicts of interest regarding the publication of this paper.

\section{References}

Adam, C., Klissouras, V., Ravazzolo, M. et al. (1988). EUROFIT: European Test of Physical Fitness. Rome: Council of Europe, Committee for the Development of Sport.

Androutsos, O., Apostolidou, E., Iotova, V., Socha, P., Birnbaum, J., Moreno, L., De Bourdeaudhuij, I., Koletzko, B., \& Manios, Y. (2014). Process Evaluation Design and Tools Used in a Kindergarten-Based, Family-Involved Intervention to Prevent Obesity in Early Childhood. The ToyBox Study. Obesity Reviews, 15, 74-80. https://doi.org/10.1111/obr.12185

Beets, M. W., Okely, A., Weaver, R. G., Webster, C., Lubans, D., Brusseau, T., Carson, R., \& Cliff, D. P. (2016). The Theory of Expanded, Extended, and Enhanced Opportunities for Youth Physical Activity Promotion. International Journal of Behavioral Nutrition and Physical Activity, 13, 120. https://doi.org/10.1186/s12966-016-0442-2 
Bershwinger, T., \& Brusseau, T. A. (2013). The Impact of Classroom Activity Breaks on the School-Day Physical Activity of Rural Children. International Journal of Exercise Science, 6, 134-143.

Borg, G. (1998). Borg's Perceived Exertion and Pain Scales. Champaign, IL: Human Kinetics.

Brickenkamp, R., \& Zillmer, E. (1998). The d2 Test of Attention. Seattle, WA: Hogrefe and Huber Publishers. https://doi.org/10.1037/t03299-000

Bullock, A., Sheff, K., Moore, K., \& Manson, S. (2017). Obesity and Overweight in American Indian and. AJPH, 107, 1502-1508. https://doi.org/10.2105/AJPH.2017.303904

Calella, P., Mancusi, C., Pecoraro, P., Sensi, S., Sorrentino, C., Imoletti, M., Valerio, G. et al. (2019). Classroom Active Breaks: A Feasibility Study in Southern Italy. Health Promotion International, 35, e5888. https://doi.org/10.1093/heapro/daz033

Calvert, H. G., Mahar, M. T., Flay, B., \& Turner, L. (2017). Classroom-Based Physical Activity: Minimizing Disparities in School-Day Physical Activity among Elementary School Students. Journal of Physical Activity \& Health, 15, 161-168. https://doi.org/10.1123/jpah.2017-0323

Carlson, J. A., Engelberg, J. K., Cain, K. L., Conway, T. L., Mignano, A. M., Bonilla, E. A., Sallis, J. F. et al. (2015). Implementing Classroom Physical Activity Breaks : Associations with Student Physical Activity and Classroom Behavior. Preventive Medicine, 81, 67-72. https://doi.org/10.1016/j.ypmed.2015.08.006

Chafouleas, S. M., Kilgus, S. P., Jaffery, R., Riley-Tillman, T. C., Welsh, M., \& Christ, T. J. (2013). Direct Behavior Rating as a School-Based Behavior Screener for Elementary and Middle Grades. Journal of School Psychology, 51, 367-385.

https://doi.org/10.1016/j.jsp.2013.04.002

Chan, Y. Y., Lim, K. K., Lim, K. H., Teh, C. H., Kee, C. C., Cheong, S. M., Ahmad, N. A. et al. (2017). Physical Activity and Overweight/Obesity among Malaysian Adults: Findings from the 2015 National Health and Morbidity Survey (NHMS). BMC Public Health, 17, Article No. 733. https://doi.org/10.1186/s12889-017-4772-Z

Cianchetti, C., Corona, S., Foscoliano, M., Contu, D., \& Sannio-Fancello, G. (2007). Modified Wisconsin Card Sorting Test (MCST, MWCST): Normative Data in Children 4-13 Years Old, According to Classical and New Types of Scoring. Clinical Neuropsychology, 21, 456-478. https://doi.org/10.1080/13854040600629766

de Greeff, J. W., Hartman, E., Bosker, R. J., Doolaard, S., \& Visscher, C. (2016b). Long-Term Effects of Physically Active Academic Lessons on Physical Fitness and Executive Functions in Primary School Children. Health Education Research, 31, 185-194. https://doi.org/10.1093/her/cyv102

de Greeff, J. W., Hartman, E., Mullender-Wunsma, M., Bosker, R. J., Dollard, S., \& Visscher, C. (2016a). Effect of Physically Active Academic Lessons on Body Mass Index and Physical Fitness in Primary School Children. Journal of School Health, 86, 346-352. https://doi.org/10.1111/josh.12384

Dewitt, S., Hall, J., Smith, L., Buckley, J. P., Biddle, S. J. H., Mansfield, L., \& Gardner, B. (2019). Office Workers' Experiences of Attempts to Reduce Sitting-Time: An Exploratory, Mixed-Methods Uncontrolled Intervention Pilot Study. BMC Public Health, 19, Article No. 819. https://doi.org/10.1186/s12889-019-7196-0

Donnelly, J. E., \& Lambourne, K. (2011). Classroom-Based Physical Activity, Cognition, and Academic Achievement. Preventive Medicine, 52, S36-S42. https://doi.org/10.1016/j.ypmed.2011.01.021

Donnelly, J. E., Hillman, C. H., Castelli, D., Etnier, J. L., Lee, S., Tomporowski, P., Lambourne, K., \& Szabo-Reed, A. N. (2016). Physical Activity, Fitness, Cognitive Function, and Academic Achievement in Children: A Systematic Review. Medicine \& Science in 
Sports \& Exercise, 48, 1197-1222.

https://doi.org/10.1249/MSS.0000000000000901

Donnelly, J. E., Hillman, C. H., Greene, J. L., Hansen, D. M., Gibson, C. A., Sullivan, D. K., Washburn, R. A. et al. (2017). Physical Activity and Academic Achievement across the Curriculum: Results from a 3-Year Cluster-Randomized Trial. Preventive Medicine, 99, 140-145. https://doi.org/10.1016/j.ypmed.2017.02.006

Ebesutani, C., Regan, J., Smith, A., Reise, S., Higa-McMillan, C., \& Chorpita, B. F. (2012). The 10-Item Positive and Negative Affect Schedule for Children, Child and Parent Shortened Versions: Application of Item Response Theory for More Efficient Assessment. Journal of Psychopathology and Behavioral Assessment, 34, 191-203. https://doi.org/10.1007/s10862-011-9273-2

Erwin, H., Koufroudakis, R., \& Beighle, A. (2013). Children's Physical Activity Levels during Indoor Recess Dance Videos. Journal of School Health, 83, 322-327. https://doi.org/10.1111/josh.12034

Fu, Y., \& Burns, R. D. (2018). Effect of an Active Video Gaming Classroom Curriculum on Health-Related Fitness, School Day Step Counts, and Motivation in Sixth Graders. Journal of Physical Activity and Health, 15, 644-650. https://doi.org/10.1123/jpah.2017-0481

Gao, Z., Newton, M., \& Carson, R. L. (2008). Students' Motivation, Physical Activity Levels, and Health-Related Physical Fitness in Middle School Physical Education. MGRJ, 3, 21-39.

Glapa, A., Grzesiak, J., Laudanska-KrzeminskaId, I. L., Chin, M.-K., Edginton, C. R., Mok, M. M. C., \& Bronikowski, M. (2018). The Impact of Brain Breaks Classroom-Based Physical Activities on Attitudes toward Physical Activity in Polish School Children in Third to Fifth Grade. International Journal of Environmental Research and Public Health, 15, 368-378. https://doi.org/10.3390/ijerph15020368

Goudas, M., \& Dermitzaki, I. (2004). Participation Motives in Physical Education: An Expectancy-Value Approach. Perceptual and Motor Skills, 99, 1168-1170. https://doi.org/10.2466/PMS.99.7.1168-1170

Guay, F., Vallerand, R. J., \& Blanchard, C. (2000). On the Assessment of Situational Intrinsic and Extrinsic Motivation: The Situational Motivation Scale (SIMS). Motivation and Emotion, 24, 175-213. https://doi.org/10.1023/A:1005614228250

Guthold, R., Stevens, G. A., Riley, L. M., \& Bull, F. C. (2019). Global Trends in Insufficient Physical Activity among Adolescents: A Pooled Analysis of 298 Population-Based Surveys with 1.6 Million Participants. The Lancet Child and Adolescent Health, 4642, 1-13. https://doi.org/10.1016/S2352-4642(19)30323-2

Harris, H. B., \& Chen, W. (2018). Technology-Enhanced Classroom Activity Breaks Impacting Children's Physical Activity and Fitness. Journal of Clinical Medicine, 7, 165. https://doi.org/10.3390/jcm7070165

Harter, S. (1978). Effectance Motivation Reconsidered. Toward a Developmental Model. Early Human Development, 21, 34-64. https://doi.org/10.1159/000271574

Huotari, P., Heikinaro-Johansson, P., Watt, A., \& Jaakkola, T. (2018). Fundamental Movement Skills in Adolescents: Secular Trends from 2003 to 2010 and Associations with Physical Activity and BMI. Scandinavian Journal of Medicine \& Science in Sports 28, 1121-1129. https://doi.org/10.1111/sms.13028

Kao, S. C., Drolette, E. S., Scudder, M. R., Raine, L. B., Westfall, D. R., Pontifex, M. B., \& Hillman, C. H. (2018). Aerobic Fitness Is Associated with Cognitive Control Strategy in Preadolescent Children. Journal of Motor Behavior, 49, 150-162. https://doi.org/10.1080/00222895.2016.1161594 
Lee, S. W., Shaftel, J., Neaderhiser, J., \& Oeth, J. (2009). Development and Validation of Instruments to Assess the Behavior and Assets of Students at the Classroom Level. Paper Presented at the Annual Meeting of the American Psychological Association, Toronto, CA.

Lonsdale, C., Sanders, T., Cohen, K. E., Parker, P., Noetel, M., Hartwig, T., Vasoncellos, D., Kirwan, M., Morgan, P., Salmon, J., Moodie, M., McKay, H., Bennie, A., Plotnikoff, R., Cinelli, R. L., Greene, D., Peralta, L. R., Cliff, D. P., Kolt, G. S., Gore, J. M., Gao, L., \& Lubans, D. R. (2016). Scaling-Up an Efficacious School-Based Physical Activity Intervention: Study Protocol for the "Internet-Based Professional Learning to Help Teachers Support Activity in Youth" (iPLAY) Cluster Randomized Controlled Trial and Scale-Up Implementation Evaluation. BMC Public Health, 16, Article No. 873. https://doi.org/10.1186/s12889-016-3243-2

Mahar, M. T. (2011). Impact of Short Bouts of Physical Activity on Attention-to-Task in Elementary School Children. Preventive Medicine, 52, 60-64.

https://doi.org/10.1016/j.ypmed.2011.01.026

Martin, R., \& Murtagh, E. M. (2015). Preliminary Findings of Active Classrooms: An Intervention to Increase Physical Activity Levels of Primary School Children during Class Time. Teaching and Teacher Education, 52, 113-127. https://doi.org/10.1016/j.tate.2015.09.007

Martin, R., \& Murtagh, E. M. (2016). Active Classrooms: A Cluster Randomised Controlled Trial Evaluating the Effects of a Movement Integration Intervention on the Physical Activity Levels of Primary School Children. Journal of Physical Activity \& Health, 14, 290-300. https://doi.org/10.1123/jpah.2016-0358

Meredith, M. D., \& Welk, G. J. (2010). Fitnessgram/Actvitygram Test Administration Manual (4th ed.). Champaign, IL: Human Kinetics.

Moher, D., Liberati, A., Tetzlaff, J., \& Altman, D. G. (2009). Preferred Reporting Items for Systematic Reviews and Meta-Analyses: The PRISMA Statement. PLoS Medicine, 6, e1000097. https://doi.org/10.1371/journal.pmed.1000097

Mok, M. M. C., Chin, M. K., Chen, S., Emeljanovas, A., Mieziene, B., Bronikowski, M., Laudanska-Krzeminska, I., Milanovic, I., Pasic, M., Balasekaran, G., Phua, K. W., \& Makaza, D. (2015). Psychometric Properties of the Attitudes toward Physical Activity Scale: A Rasch Analysis Based on Data from Five Locations. Journal of Applied Measurement, 16, 379-400. https://doi.org/10.1037/t58102-000

NCD Risk Factor Collaboration (NCD-RisC) (2017). Worldwide Trends in Body-Mass Index, Underweight, Overweight, and Obesity from 1975 to 2016: A Pooled Analysis of 2416 Population-Based Measurement Studies in 128.9 Million Children, Adolescents, and Adults. The Lancet, 390, 2627-2642. https://doi.org/10.1016/S0140-6736(17)32129-3

Norton, K., Norton, L., \& Sadgrove, D. (2010). Position Statement on Physical Activity and Exercise Intensity Terminology. Journal of Science and Medicine in Sport, 13, 496-502. https://doi.org/10.1016/j.jsams.2009.09.008

Ommundsen, Y., Page, A., Ku, P. W., \& Cooper, A. R. (2008). Cross-Cultural, Age and Gender Validation of a Computerised Questionnaire Measuring Personal, Social and Environmental Associations with Children's Physical Activity: The European Youth Heart Study. The International Journal of Behavioral Nutrition and Physical Activity, 5, 29. https://doi.org/10.1186/1479-5868-5-29

Popeska, B., Jovanova-Mitkovska, S., Chin, M., \& Edginton, C. R. (2018). Implementation of Brain Breaks ${ }^{\circledast}$ in the Classroom and Effects on Attitudes toward Physical Activity in a Macedonian School Setting. International Journal of Environmental Research and Public Health, 15, 1127. https://doi.org/10.3390/ijerph15061127 
Samuels, S. E., Craypo, L., Boyle, M., Crawford, P. B., Yancey, A., \& Flores, G. (2010). The California Endowment's Healthy Eating, Active Communities Program: A Midpoint Review. American Journal of Public Health, 100, 2114-2123. https://doi.org/10.2105/AJPH.2010.192781

Scanlan, T. K., Carpenter, P. J., Schmidt, G. W., Simons, J. P., \& Keeler, B. (1993). An Introduction to the Sport Commitment Model. International Journal of Sport and Exercise Psychology, 15, 1-15. https://doi.org/10.1123/jsep.15.1.1

Schmidt, M., Benzing, V., \& Kamer, M. (2016). Classroom-Based Physical Activity Breaks and Children's Attention: Cognitive Engagement Works! Frontiers in Psychology, 7, 1474. https://doi.org/10.3389/fpsyg.2016.01474

Sneck, S., Viholainen, H., Syvaoja, H., Kankaapaa, A., Hakonen, H., Poikkeus, A.-M., \& Tammelin, T. (2019). Effects of School-Based Physical Activity on Mathematics Performance in Children: A Systematic Review. The International Journal of Behavioral Nutrition and Physical Activity, 16, 109. https://doi.org/10.1186/s12966-019-0866-6

Strauss, E. H., Sherman, E. M. S., \& Spreen, O. (2006). A Compendium of Neuropsychological Tests: Administration, Norms, and Commentary. New York: Oxford University Press.

Szabo-Reed, A. N., Willis, E. A., Lee, J., Hillman, C. H., Washburn, R. A., \& Donnelly, J. E. (2019). The Influence of Classroom Physical Activity Participation and Time on Task on Academic Achievement. Translational Journal of the American College of Sports Medicine, 4, 84-95.

Turner, L., \& Chaloupka, F. J. (2016). Reach and Implementation of Physical Activity Breaks and Active Lessons in Elementary School Classrooms. Health Education \& Behavior, 44, 370-375. https://doi.org/10.1177/1090198116667714

UNESCO. United Nations Educational, Scientific and Cultural Organization (2012). International Standard Classification of Education ISCED 2011. Montreal: UNESCO Institute for Statistics.

Watson, A. J. L., Timperio, A., Brown, H., \& Hesketh, K. D. (2018). A Pilot Primary School Active Break Program (ACTI-BREAK): Effects on Academic and Physical Activity Outcomes for Students in Years 3 and 4. Journal of Science and Medicine in Sport, 22, 438-443. https://doi.org/10.1016/j.orcp.2018.11.071

Wechsler, D. (1987). WMS-R: Wechsler Memory Scale-Revised: Manual. San Antonio, TX: Psychological Corporation.

Westwood, P. S. (2000). One Minute Test of Basic Number Facts. In Numeracy and Learning Difficulties: Approaches to Teaching and Assessment (p. 108). Camberwell: ACER Press.

Wheldall, K., \& Madelaine, A. (2013). Manual for the Wheldall Assessment of Reading Passages (WARP). Sydney: Multilit Pty Ltd.

Whitt-glover, M. C., Ham, S. A., \& Yancey, A. K. (2011). Instant Recess ${ }^{\oplus}$ : A Practical Tool for Increasing Physical Activity during the School Day. Progress in Community Health Partnerships: Research, Education, and Action, 5, 289-297. https://doi.org/10.1353/cpr.2011.0031

WHO. World Health Organization (2014). World Health Statistics. Geneva: World Health Organization.

Xiang, P., McBride, R., \& Bruene, A. (2006). Fourth Grader Students' Motivational Changes in an Elementary Physical Education Running Program. Research Quarterly for Exercise and Sport, 77, 195-207. https://doi.org/10.1080/02701367.2006.10599354 